\title{
Trioecy in Coccoloba cereifera Schwacke (Polygonaceae), a Narrow Endemic and Threatened Tropical Species
}

\author{
Celice Alexandre Silva ${ }^{1 *}$, Marco Antonio Oliva ${ }^{2}$, Milene Faria Vieira ${ }^{2}$ and Geraldo Wilson \\ Fernandes $^{3}$ \\ ${ }^{1}$ Departamento de Ciências Biológicas; Universidade do Estado do Mato Grosso; \\ celicealexandre645@hotmail.com; 78300-000; Tangará da Serra - MT - Brasil. ${ }^{2}$ Departamento de Biologia \\ Vegetal; Universidade Federal de Viçosa; 36570-000; Viçosa - MG - Brasil. ${ }^{3}$ Laboratório de Ecologia Evolutiva \& \\ Biodiversidade; Universidade Federal de Minas Gerais; Av. Antônio Carlos, 6627; C.P.: 486; 30161-970; Belo \\ Horizonte - MG - Brasil
}

\begin{abstract}
Trioecy, the co-occurrence of the males, females, and hermaphrodite morphs in natural populations, is a rare and poorly studied breeding system. It is expressed in Coccoloba cereifera, an endemic, and endangered species from the rupestrian fields of Serra do Cipó, southeastern Brazil. Male individuals produce staminate flowers but no fruits. Female individuals produce pistillate flowers and set fruits. Both staminate and pistillate flowers present non-functional organs of the opposite sex that simulate perfect flowers. Hermaphrodite individuals produce two different perfect flowers, each one belonging to distinct individuals, and set fruits. Perfect flowers differ in the amount of pollen produced, in pollen viability, and in some morphological traits. Two Hymenoptera species visited the flowers sporadically. The low natural fructification indicated a limited pollination, while the fruit set recorded in bagged pistillate flowers indicated agamospermy. Female individuals represent more than $40 \%$ of the population studied and must be the result of agamospermic seeds.
\end{abstract}

Key words: agamospermy, breeding systems, Coccoloba cereifera, sex determination, sexual morphs, trioecy

\section{INTRODUCTION}

Trioecy is a rare and poorly studied breeding system. It consists of populations comprising individuals with staminate flowers, individuals with pistillate flowers, and individuals with perfect flowers (Sakai and Weller, 1999). Clear cases of trioecy were reported in the cacti Opuntia robusta J. C. Wendl. (del Castillo and González-Espinoza, 1988), and Pachycereus pringlei (S. Watson) Britton and Rose (Fleming et al., 1994, 1998), and in the spinach (Spinacia oleracea L.; Vitale and Freeman, 1986).

The genus Coccoloba P. Browne (Polygonaceae) comprises approximately 400 species restricted to the New World, of which 45 occur in Brazil (Melo, 2004). In taxonomic treatments, the Coccoloba species have been described as monoecious and dioecious (Melo, 2000), or polygamous (Melo, 2004). However, only $C$. uvifera (L.) Jacq has its breeding system studied in

\footnotetext{
* Author for correspondence
} 
which Madriz and Ramírez (1996-1997) reported polygamodioecy.

Coccoloba cereifera is a narrowly distributed endemic species from the rupestrian fields of Serra do Cipó, Minas Gerais, southeastern Brazil (Ribeiro and Fernandes, 1999). This species has a highly aggregated distribution, and is only found in a small area of $26 \mathrm{Km}^{2}$, between 1200 and 1300 meters a.s.l. It is associated with the sandy patches formed between the rocky outcrops, poor in nutrients (Ribeiro and Fernandes, 1999, 2000).

C. cereifera is one of the most conspicuous plant species found in the extremely diverse and endemic flora of Serra do Cipó (Rizzini, 1979; Giulietti et al., 1987). Despite the enormous interest on its use as an ornamental species, the knowledge on its natural history and ecology is limited to its present distribution and some aspects of its herbivore fauna (Ribeiro et al., 2003). In addition, new difficulties for the survival of this species have emerged due to its habitat destruction caused by a road asphalting that cross its entire distribution area. Because of increasing habitat fragmentation and destruction, this species has been declared as an endangered species (Mendonça and Lins, 2000; Ribeiro and Fernandes, 2000). The present study aimed at providing the first information on the reproductive biology of $C$. cereifera. The following questions were addressed: 1) Do the flowers differ among the different genders? 2) What is the proportion of the male, female, and hermaphrodite individuals in the field? 3) Are pistillate and perfect flowers dependent of pollination for fructification? 4) Are there floral visitors?

\section{MATERIALS AND METHODS}

The study was carried out from March 2001 to December 2002, in Serra do Cipó, in the Reserva Particular Vellozia, located at the MG highway 010, $\mathrm{km} 108$ (19 $16^{\prime} 44^{\prime \prime} \mathrm{S}$ and $\left.43^{\circ} 35^{\prime} 23^{\prime \prime} \mathrm{W}\right)$, at an altitude of $1200 \mathrm{~m}$, in southeastern Brazil. The reserve represents approximately $30 \%$ of the area in which $C$. cereifera is found (see Ribeiro and Fernandes, 1999, 2000).

Serra do Cipó lies in the southernmost portion of the Espinhaço Mountains, a predominantly quartzitic elevation that extends about $1100 \mathrm{~km}$ from $10^{\circ} \mathrm{S}$ to $20^{\circ} \mathrm{S}$ (Rizzini, 1979). Above $1000 \mathrm{~m}$, sandy and shallow soils prevail, supporting a highly sclerophyllous vegetation known for its high species diversity and high levels of endemism (Giulietti et al., 1987). The climate is classified as Cwb following Köppen, with rainy summers and dry winters. The region receives an average annual rainfall of $1500 \mathrm{~mm}$ (Galvão and Nimer, 1965; Madeira and Fernandes, 1999).

C. cereifera is a shrub, 0.5 to $3.0 \mathrm{~m}$ high, and presents gemmiparous roots (Rizzini and Heringer, 1966) (Fig. 1A), responsible for its clonal propagation (Ribeiro and Fernandes, 1999). The leaves are short-petiolate, bluish-purple, strongly coriaceous and present thick silver waxy layer on the lamina (Melo, 2000). The inflorescences are spiciform, terminal or sub-terminal, erect or slightly pendulous (Fig. 1A), with hundreds of flowers. Flowers display six purplish tepals, eight stamens or eight staminodes and one pistil with trifid style or one pistillode. The pistillate and staminate flowers present non-functional organs of the opposite sex (Melo, 2000; Silva, 2003). Fruit is an achene and the diaspore fleshy of dark violet color, consisting of an achene enclosed by the perigon. The seed presents ruminate endosperm (Barroso et al., 1978). Voucher specimens of $C$. cereifera were deposited in the Herbarium of the Department of Plant Biology of the Federal University of Viçosa (VIC 26620, 26621, 26622 and 26623).

All the individuals found flowering in the field ( $\mathrm{n}$ =92) were labeled for further identification of their flower type. In an attempt to avoid the selection of individuals belonging to the same clone (see Ribeiro and Fernandes, 1999), the plants used during the study were distant from one another at least five meters. All flower types were analyzed and measured in the field, while some were collected for complementary analysis in the laboratory. Inflorescences, of each flower type, were measured (length) $(\mathrm{n}=40)$ and the number of flowers/inflorescences was recorded by counting the number of persistent pedicels (Fig. 1B, C), in dry inflorescences $(n=40)$. In pistillate and perfect flowers, the length and diameter of totally developed diaspores $(n=90)$ were measured to know the possible difference between the flower types. For each flower type, floral longevity, nectar presence, stigma receptivity, and pollen viability were recorded. To verify the presence of glucose in the floral secretion collected by visitors, a glucose enzyme test band (Glico-Fita Plus ${ }^{\circledR}$ Bayer S.A.) was used. Glucose is one of the principal sugars found in nectar (Baker and Baker, 1983). 


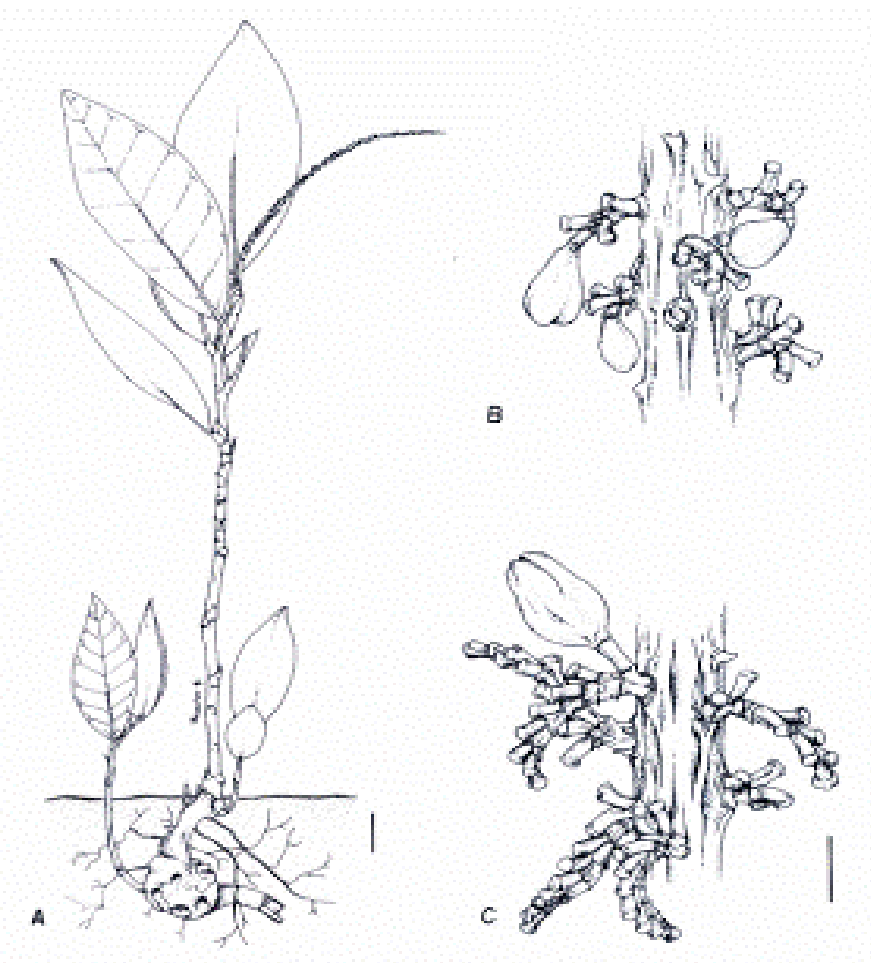

Figure 1 - Coccoloba cereifera; A: Plant; B: Detail of pistillate inflorescence; C: Detail of staminate inflorescence. Scale bar $=20 \mathrm{~mm}(\mathrm{~A})$ and $2 \mathrm{~mm}(\mathrm{~B}, \mathrm{C})$.

Stigma receptivity was tested, during the floral longevity period, using hydrogen peroxide at $3 \%$ (Dafni, 1992).

To determine the pollen grain viability, five buds were collected (before opening), from five different individuals of each flower type. All the anthers of each bud were mashed in a microscope slide, and mixed with a drop of aceto-carmim (Goldenberg and Shepherd, 1998). Up to 200 pollen grains were counted on each slide.

Two pollination experiments were conducted in the field: control, to evaluate the pollination rate under the natural conditions, and spontaneous selfpollination, to measure the need for pollinators (Dafni, 1992). For each experiment, inflorescences from all the sexual types were, respectively, tagged and left exposed to pollinators or enclosed in bags of $0.1 \mathrm{~mm}$ mesh. The percent of fruit set was calculated by considering the mean number of flowers/inflorescence of each sexual type.

To verify the growth of pollen tubes, each flower type was pollinated (selfing, except for the pistillate flowers, and out-crossing treatments). Out-crossing was carried out between flowers of different individuals from the same flower type and between flowers of different types. After 12 and $24 \mathrm{~h}$ of the treatment, flowers were preserved in $70 \%$ ethanol. The pistil of each flower was stained with aniline blue and observed under a fluorescence microscope (Martin, 1959). Flower visitors were observed over $42 \mathrm{~h}$ of daylight, i.e., over 14 non-consecutive days and for three hours/day. The insects captured were identified, and deposited in the Museum of Entomology of the Department of Animal Biology of the Federal University of Viçosa.

\section{RESULTS AND DISCUSSION}

Detailed field observations and laboratory dissection of the flowers at anthesis showed the existence of three gender types (female, male, and hermaphrodite) in C. cereifera, indicating that the species is trioecious (sensu Sakai and Weller, 1999). Therefore, it represents a novel breeding system for the Polygonaceae (see Yampolsky and Yampolsky, 1922). Each gender exhibited a different flowers type: females had pistillate flowers, male had staminate flowers, while hermaphrodites had perfect flowers (Fig. 2). 

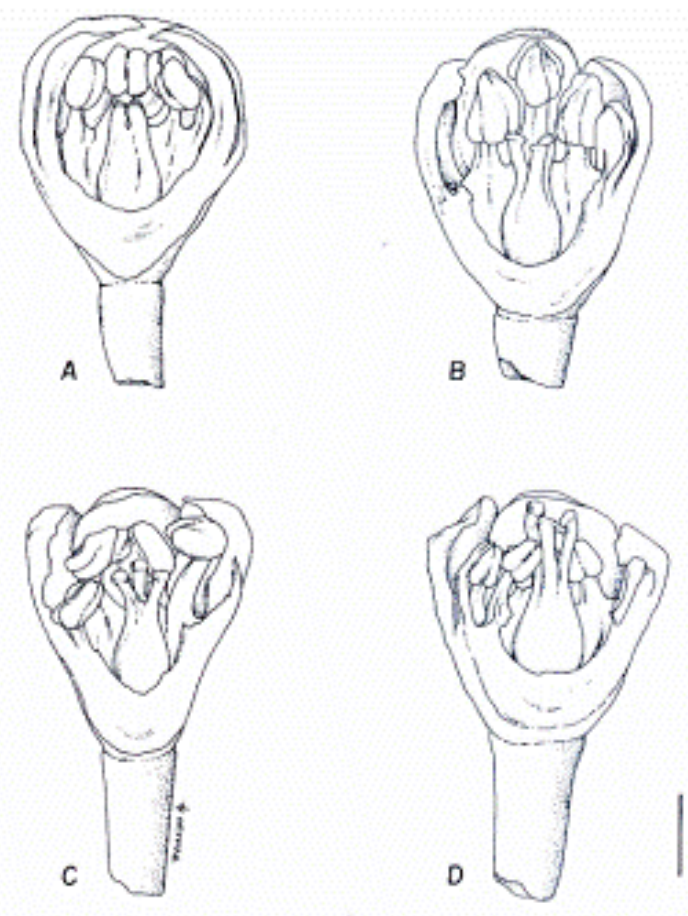

Figure 2 - Flowers types of Coccoloba cereifera, in longitudinal sections; A: staminate flower. The pistillode is located below the anthers; B: perfect flower type P1. The stigmas are located right below the anthers; C: perfect flower type P2. The stigmas are located at medium height of the anthers; D: pistillate flower. The stigmas are located above the staminodes. Scale bar $=1 \mathrm{~mm}$.

Although, pistillate and staminate flowers presented non-functional organs of the opposite sex (Fig. 2A, D), they were almost indistinct from the perfect flowers (Fig. 2B, C) found in the hermaphrodite individuals. Thus, the distinction of $C$. cereifera's gender in the field is complex.

Flowers with non-functional organs of the opposite sex have been recorded both in trioecious and subdioecious species (Fleming et al., 1994; Strittmatter et al., 2002). Strittmatter et al. (2002) reported that the non-functional anthers in pistillate flowers could have been maintained because they are adaptive, i.e., they mimic the appearance of the anthers of the male and hermaphrodite types, aiding in pollinator attraction. It is possible that the resemblance of the different flower types of $C$. cereifera could also represent a case of self-mimicry.

As expected, the staminate flowers of $C$. cereifera did not set fruits (Table 1). The anthers of staminate flowers with fertile pollen grains (Table 2) were inserted above the pistillode, which had a short trifid style (Fig. 2A). The pistillate flowers set fruits (Table 1). The stigmas of these flowers were inserted above the staminodes and the pistil had a long trifid style (Fig. 2D). The staminodes had non-dehiscent anthers and lacked pollen grains. The hermaphrodite individuals produced two different types of perfect flowers. Each flower type belonged to distinct individuals, and set fruits (Table 1). For the purpose of this study, these types are hereafter called P1 and P2. They possessed a functional androecium with fertile pollen grains, and a functional gynoecium. On the other hand, pollen viability was lower than in the staminate flowers (Table 2). The pistil, in both types, had a trifid style of intermediary size in relation to the staminate and pistillate flowers (Fig. 2B, C). A difference in the amount of pollen produced was observed, as well as in pollen viability between P1 and P2 types (Table 2). They also differed in the position of the stigmas in relation to the anthers (Fig. $2 \mathrm{~B}, \mathrm{C}$ ). In type P1, the stigmas were inserted right below the anthers (Fig. 2B), while in type $\mathrm{P} 2$, the stigmas were inserted at the median height of the anthers (Fig. 2C). 
In $C$. cereifera, the $\mathrm{P} 1$ flowers resembled staminate flowers, while the $\mathrm{P} 2$ flowers resembled pistillate flowers. The evolution of dioecy from the hermaphroditism may have involved an intermediate type of population that contained hermaphrodites and female plants (gynodioecy) or hermaphrodites and male plants (androdioecy) (Charlesworth and Charlesworth, 1978; Bawa, 1980; Richards, 1997), or hermophrodites and female and male plants (trioecy) (del Castillo and González-Espinoza, 1988). An interesting question to be addressed is whether this divergence among the perfect flowers will result in their disappearance, leading the species toward dioecy.

All the flower types measured approximately 3 $\mathrm{mm}$ in diameter, lasted for $24 \mathrm{~h}$, and produced nectar (test for glucose was positive for all the flowers). Anthesis initiated in the morning at approximately $6: 00 \mathrm{~h}$, continued until 12:00 h, when the tepals were found totally expanded and the reproductive organs completely exposed to the floral visitors. The stigmas of the pistillate and perfect flowers remained receptive throughout the period in which the flowers lasted, after which the perigon closed itself over the androecium and gynoecium. The perigon also closed itself over the pistillode of staminate flowers. Then, the flowers reacquired the aspect of a floral bud.

The diaspores resulting from the pistillate flowers were longer than those produced by perfect flowers (Table 3; $\mathrm{df}=2, \mathrm{~F}=8.89, \mathrm{P}=0.0013$ ). However, their diameters were not different $(\mathrm{df}=$ $2, \mathrm{~F}=1.91, \mathrm{P}=0.168$ ).

Female plants represented more than $40 \%$ of the individuals sampled (Table 3 ). The proportion of individuals was as follow: $1 \delta^{\lambda}: 2.59: 1.6 \mathrm{P} 1: 1 \mathrm{P} 2$. Although the inflorescence length of each individual was, on average, similar, males produced an average of 1.7 to 2.2 times more flowers/inflorescence than the other gender types (Table 3). Madriz and Ramírez (1996-1997) also recorded a higher production of flowers in the male inflorescences in C. uvifera. Higher production of staminate flowers has also been found in dioecious species (e.g., Armstrong and Irvine, 1989; Piratelli et al., 1998). Although larger floral displays have been shown to increase the removal of pollen (Willson and Price, 1977), the low natural fructification in C. cereifera (Table 1) indicated the limited pollination.

Table 1 - Results of free pollination (control) and selfing in flowers of Coccoloba cereifera: $\mathrm{P} 1$ = perfect flower type $1, \mathrm{P} 2$ = perfect flower type 2 . The number of flowers was calculated based on the mean number of flowers per inflorescence (Table 3).

\begin{tabular}{|c|c|c|c|c|c|}
\hline Treatment/ & Individ. & Infloresc. & Flower & & \\
\hline Flower type & $\mathbf{n}$ & $\mathbf{n}$ & $\mathbf{n}$ & $\mathbf{n}$ & $\%$ \\
\hline \multicolumn{6}{|l|}{ Control/ } \\
\hline Staminate & 5 & 5 & 4875 & 0 & 00.00 \\
\hline P1 & 5 & 5 & 2235 & 66 & 02.95 \\
\hline $\mathrm{P} 2$ & 5 & 5 & 2630 & 15 & 00.57 \\
\hline Pistillate & 5 & 5 & 2925 & 232 & 07.93 \\
\hline \multicolumn{6}{|l|}{ Selfing/ } \\
\hline Staminate & 5 & 5 & 4875 & 0 & 00.00 \\
\hline $\mathrm{P} 1$ & 5 & 5 & 2235 & 24 & 01.07 \\
\hline $\mathrm{P} 2$ & 4 & 4 & 2104 & 7 & 00.33 \\
\hline Pistillate & 5 & 5 & 2925 & 584 & 19.96 \\
\hline
\end{tabular}

In the selfing treatment, null fructification was expected in both the staminate and pistillate flowers. However, larger fructification was recorded in the pistillate flowers (Table 1), indicating that $C$. cereifera is agamospermic, with no possibility of pseudogamy. On the other hand, agamospermy seemed to be partial, since in perfects flowers, in both control and selfing treatments, presented fructification at least 18 times lower compared to the pistillate flowers (Table 1). In this case, the fruits produced by the perfect flowers must be the result of selffertilization, since these flowers presented the pollen with high viability (Table 2) and no 
herkogamy exists (Fig. 2B, C). The perfect flowers in the control treatment produced approximately 2.5 times more fruits than in the selfing treatment (Table 1), perhaps due to the action of pollinators. Pollen tubes reached the ovary in all the floral types, except in the staminate flowers, corroborating that its gynoecium is non-functional. These data indicate that perfect flowers are dependent on the pollination (selfing or crossing) for the seed production.

Table 2 - Number of pollen grain per lamina (up to 200) and pollen viability in different flowers types of Coccoloba cereifera. $\mathrm{P} 1=$ perfect flower type $1, \mathrm{P} 2=$ perfect flower type 2 . Means followed by different letter differ statistically by the Tukey test, at $5 \%$ probability.

\begin{tabular}{lccc}
\hline Flower type & \multicolumn{2}{c}{ Number of pollen grains per flower } & Pollen viability \\
\hline & Range & $\bar{X} \pm$ SD & $\%$ \\
\hline Staminate & $151-200$ & $198.04 \pm 9.80$ & $86.60 \mathrm{a}$ \\
P1 & $27-200$ & $132.00 \pm 53.47$ & $80.60 \mathrm{~b}$ \\
P2 & $7-102$ & $47.00 \pm 45.32$ & $73.00 \mathrm{c}$ \\
\hline
\end{tabular}

Table 3 - Individuals with pistillate, staminate and perfect flowers, length of inflorescences and number of flowers per inflorescence in different floral types of Coccoloba cereifera: $\mathrm{P} 1=$ perfect flower type $1, \mathrm{P} 2$ = perfect flower type 2 . Means followed by the same letter do not differ statistically by the Tukey test, at $5 \%$ probability.

\begin{tabular}{lccccccc}
$\begin{array}{l}\text { Flower } \\
\text { type }\end{array}$ & $\begin{array}{c}\text { Individuals } \\
(\%)\end{array}$ & $\begin{array}{c}\text { Inflorescence length } \\
(\mathbf{c m})\end{array}$ & \multicolumn{2}{c}{$\begin{array}{c}\text { Number of flowers per } \\
\text { inflorescence }\end{array}$} & \multicolumn{2}{c}{ Diaspores } \\
\hline & & Range & $\bar{X} \pm$ SD & Range & $\bar{X} \pm$ SD & Length & Diameter $(\bar{X})$ \\
\hline Staminate & 16.3 & $16-26$ & $19.50 \pm 3.86$ & $699-1680$ & $975 \pm 290.91$ & - & - \\
P1 & 26.1 & $15-20$ & $19.30 \pm 2.35$ & $200-618$ & $447 \pm 110.05$ & $7.55 \mathrm{~b}$ & 5.85 \\
P2 & 16.3 & $12-28$ & $20.10 \pm 5.62$ & $480-689$ & $585 \pm 65.81$ & $7.75 \mathrm{~b}$ & 6.40 \\
Pistillate & 41.3 & $17-32$ & $22.10 \pm 4.97$ & $228-710$ & $526 \pm 139.60$ & $8.40 \mathrm{a}$ & 5.89 \\
\hline
\end{tabular}

Agamospermy has been reported in few species of Polygonaceae such as Acetosa arifolia (All.) Schur, A. thyrsiflora (Fingerh.) Á. Löve and D. Löve (Nygren, 1954), and Atraphaxis frutescens (L.) Eversm. (Asker and Jerling, 1992). Three facts pointed out to partial agamospermy in $C$. cereifera: 1) the high pollen viability; 2) the growth of pollen tubes up to the ovary in all pistillate flowers; and 3) the lower fruit set of perfect flowers (P1 and P2). In apomictic species, relatively low levels of pollen viability were accompanied by high agamospermic seed production (Goldenberg and Shepherd, 1998). Antennaria parlinii Fernald (Asteraceae) also displayed partial agamospermy. For this dioecious species, agamospermy was recorded on a population that had only female individuals. In the mixed-sex populations, the seed production appeared strongly dependent on the pollination (O'Connell and Eckert, 1999).
The larger number of female individuals of $C$. cereifera compared to hermaphrodites and males must be the result of agamospermy. Agamospermic seeds of dioecious species produce only the individuals with pistillate flowers (Harper, 1982; Bayer and Stebbins, 1983; O'Connell and Eckert, 1999). Therefore, agamospermy apparently prevailed over the sexual reproduction, resulting in an unbalanced proportion among the gender types. The agamospermy in C. cereifera may be a strategy for the colonization, allowing the population to persist in a territory where the pollen or pollinators are depleted. According to Dupont (2002), the evolution of apomixis in the dioecious species Lindera glauca Sieb. and Zucc. (Lauraceae) was a strategy of colonization to ensure the reproduction even in the absence of male individuals. 
Only two hymenopteran species were observed during the present study: the bee Trigona spinipes (Fabricius 1793) (Apidae) and the wasp Brachygastra sp. (Vespidae). These insects visited the flowers sporadically, especially in the morning to collect the nectar. During the visits, they contacted the anthers and/ or stigmas. The flowers of $C$. cereifera, such as those of dioecious species (Bawa and Opler, 1975, Madriz and Ramírez 1996-1997), are small and considered to be nonspecialized, i.e., they can attract several small insects. However, the low number of visits to $C$. cereifera flowers may be related to their occurrence at high altitudes, where potential pollinating invertebrates are restricted to anthophilous animals, especially social insects (e.g., Trigona spinipes) (Faria, 1994). Small hymenopterans, similarly to the ones recorded in this study, were observed on the flowers of $C$. uvifera (Trigona and wasps) (Madriz and Ramírez, 1996-1997) and flowers of C. acrostichioides (Cham.) (the bees Ceratinula sp., Augochlora sp. and Dialictus sp.; M. A. Melo, pers. comm.). These results indicate that the small insects, especially Hymenoptera, may act as pollinators of Coccoloba species. However, further field studies are needed to accurately discover the pollinators of these species.

\section{ACKNOWLEDGEMENTS}

We thank C. Garcia-Robledo, C. M. Jacobi, and L. $\mathrm{R}$. Viana for comments on an earlier version of the $\mathrm{ms}$, and L. M. Araújo for field assistance. Financial support was provided by $\mathrm{CNPq}$ (47 9684/2001-4, 30 4851/2004-3), Fapemig (CRA 388/01, 583/03), and Planta Tecnologia Ambiental. This research was also supported by a CAPES Master scholarship granted to the first author at the Department of Plant Biology of the Federal University of Viçosa.

\section{RESUMO}

A trioicia, a coocorrência, em população natural, de indivíduos masculinos, femininos e hermafroditas, é um sistema reprodutivo raro e pouco estudado. Coccoloba cereifera (Polygonaceae), espécie endêmica e em perigo de extinção dos campos rupestres da Serra do Cipó, sudeste brasileiro, apresenta esse sistema. Indivíduos masculinos produzem flores estaminadas e não frutificam. Indivíduos femininos produzem flores pistiladas e frutificam. Ambas flores estaminadas e pistiladas apresentam órgãos não-funcionais do sexo oposto, tornando-as semelhantes às flores perfeitas. Indivíduos hermafroditas produzem dois tipos de flores perfeitas, cada um pertencente a indivíduos distintos, e ambos frutificam. As flores perfeitas diferem entre si na quantidade de pólen produzido, na viabilidade do pólen e em algumas características morfológicas. Duas espécies de Hymenoptera visitaram as flores esporadicamente. A baixa frutificação natural indicou uma polinização limitada, ao passo que a frutificação registrada em flores pistiladas, isoladas por sacos, indicou agamospermia. Indivíduos femininos representaram mais que $40 \%$ da população estudada e devem ser resultantes de sementes agamospérmicas.

\section{REFERENCES}

Armstrong, J. E. and Irvine, A. K. (1989), Flowering, sex ratios, pollen-ovule ratios, fruit set, and reproductive effort of a dioecious tree, Myristica insipida $\mathrm{R}$. Br. (Myristicaceae), in two different rain forest communities. Amer. J. Bot., 76, 74-85.

Asker, S. E. and Jerling, L. (1992), Apomixis in plants. CRC Press, Boca Raton.

Baker, H. G. and Baker, I. (1983), Floral nectar sugar constituents in relation to pollinator type. InHandbook of Experimental Pollination Biology, eds. C. E. Jones and R. J. Little. Van Nostrand Reinhold Company Inc., New York, pp. 117-141.

Barroso, G. M.; Guimarães, E. F.; Ichaso, C. L. F.; Costa, C. G. and Peixoto, A. L. (1978), Sistemática de angiospermas do Brasil. Editora da Universidade de São Paulo, São Paulo.

Bawa, K. S. (1980), Evolution of dioecy in flowering plants. Ann. Rev. Ecol. Syst., 11, 15-39.

Bawa, K. S. and Opler, P. A. (1975), Dioecism in tropical forest trees. Evolution, 329, 167-179.

Bayer, J. R. and Stebbins, G. L. (1983), Distribution of sexual and apomictic populations of Antennaria parlinii. Evolution, 37, 555-561.

Charlesworth, B. and Charlesworth, D. (1978), A model for the evolution of dioecy and gynodioecy. Am. Nat., 112, 975-997.

Dafni, A. (1992), Pollination ecology - A practical approach. Oxford University Press, Oxford. 
del Castillo, R. F. and González-Espinoza, M. (1988), Una interpretación evolutiva del polimorfismo sexual de Opuntia robusta (Cactaceae). Sobret. Agroc., 71, 185-196.

Dupont, Y. L. (2002), Evolution of apomixis as a strategy of colonization in the dioecious species Lindera glauca (Lauraceae). Popul. Ecol., 44, 293297.

Faria, G. M. (1994), A flora e a fauna apícola de um ecossistema de campo rupestre, Serra do Cipó - MG, Brasil: composição, fenologia e suas interações. Ph.D Thesis, Universidade Estadual Paulista, Ribeirão Preto, Brazil.

Fleming, T. H.; Maurice, S.; Buchmann, S. L. and Tuttle, M. D. (1994), Reproductive biology and relative male and female fitness in a trioecious cactus, Pachycereus pringlei (Cactaceae). Amer. J. Bot., 81, 858-867.

Fleming, T. H.; Maurice, S. and Hamrick, J. L. (1998) Geographic variation in the breeding system and the evolutionary stability of trioecy in Pachycereus pringlei (Cactaceae). Evol. Ecol., 12, 279-289.

Galvão, M. V. and Nimer, E. (1965), Clima. InGeografia do Brasil - Grande Região Leste. IBGE, Rio de Janeiro, pp. 91-139.

Giulietti, A. M.; Menezes, N. L.; Pirani, J. R.; Meguro, M. and Wanderley, M. G. L. (1987), Flora da Serra do Cipó, Minas Gerais: caracterização e lista de espécies. Bol. Bot. Univ. São Paulo, 9, 11-151.

Goldenberg, R. and Shepherd, G. J. (1998), Studies on the reproductive biology of Melastomataceae in "cerrado" vegetation. Plant Syst. Evol., 211, 13-29.

Harper, A. B. (1982), The selective significance of partial apomixis. Heredity, 48, 107-116.

Madeira, J. A. and Fernandes, G. W. (1999), Reproductive phenology of sympatric taxa of Chamaecrista (Leguminosae) in Serra do Cipó, Brazil. J. Trop. Ecol., 15, 463-479.

Madriz, R. and Ramírez, N. (1996-1997), Biología reproductiva de Coccoloba uvifera (Polygonaceae) una especie poligamo-dioica. Rev. Biol. Trop., 44/45, 105-115.

Martin, F. W. (1959), Staining and observing pollen tubes in style by means of fluorescence. Stain Technol., 34, 125-128.

Melo, E. (2000), Polygonaceae da Cadeia do Espinhaço, Brasil. Acta Bot. Bras., 14, 273-300.

Melo, E. (2004), As espécies de Coccoloba P. Browne (Polygonaceae) da Amazônia brasileira. Acta Amazon., 34, 525-551.

Mendonça, M. P. and Lins, L. V. (2000), Lista vermelha das espécies ameaçadas de extinção da flora de Minas Gerais. Fundação Biodiversitas, Belo Horizonte.

Nygren, A. (1954), Apomixis in the angiosperms. II. Bot. Rev., 20, 577-649.

O'Connell, L. M. and Eckert, C. G. (1999), Differentiation in sexuality among populations of
Antennaria parlinii (Asteraceae). Intern. J. Plant Sci., 160, 567-575.

Piratelli, A. J.; Piña-Rodrigues, F. C. M.; Gandara, F. B.; Santos, E. M. G. and Costa, L. G. S. (1998), Biologia da polinização de Jacaratia spinosa (Aubl.) A. DC. (Caricaceae) em mata residual do sudeste brasileiro. Rev. Bras. Biol., 58, 671-679.

Ribeiro, K. T. and Fernandes, G. W. (1999), Geographic distribution of Coccoloba cereifera (Polygonaceae), a narrow endemic from Serra do Cipó, Brazil. Bios, 7, 7-12.

Ribeiro, K. T. and Fernandes, G. W. (2000), Patterns of abundance of a narrow endemic species in a tropical and infertile habitat. Plant Ecol., 147, 205-218.

Ribeiro, K. T.; Codeço, C. T. and Fernandes, G. W. (2003), Local and regional spatial distribution of an eruptive and a latent herbivore insect species. Austral Ecol., 28, 99-107.

Richards, A. J. (1997), Plant breeding systems. Chapman and Hall, London.

Rizzini, C. T. (1979), Tratado de fitogeografia do Brasil: aspectos sociológicos e florísticos. Hucitec/EDUSP, São Paulo.

Rizzini, C. T. and Heringer, P. H. (1966), Estudo sobre os sistemas subterrâneos difusos de plantas campestres. An. Acad. Bras. Ciênc., 38, 85-112.

Sakai, A. K. and Weller, S. G. (1999), Gender and sexual dimorphism in flowering plants: a review of terminology, biogeographic patterns, ecological correlates, and phylogenetic approaches. In- Gender and sexual dimorphism in flowering plants. eds. M. A. Geber, T. E. Dawson and L. F. Delph. SpringerVerlag, Berlin, pp. 1-31.

Silva, C. A. (2003), Coccoloba cereifera Schwacke (Polygonaceae): aspectos ecofisiológicos e reprodutivos. MSc Thesis, Universidade Federal de Viçosa, Viçosa, Brazil.

Strittmatter, L. I.; Negrón-Ortiz, V. and Hickey, R. J. (2002), Subdioecy in Consolea spinosissima (Cactaceae): breeding system and embryological studies. Amer. J. Bot., 89, 1373-1387.

Vitale, J. J. and Freeman, D. C. (1986), Partial niche separation in Spinacia oleracea L.: an examination of reproductive allocation. Evolution, 40, 426-430.

Willson, M. F. and Price, P. W. (1977), The evolution of inflorescence size in Asclepias (Asclepiadaceae). Evolution, 31, 495-511.

Yampolsky, C. and Yampolsky, H. (1922), Distribution of sex forms in the phanerogamic flora. Bibl. Genet., 3, 1-62. 